\title{
Relevant Conceptions on the Inheritance and Protection of Manchu Music in Liaoning Province
}

\author{
Yan Zhou \\ Anshan Normal College \\ Anshan, China
}

\begin{abstract}
Manchu culture has a long history and rich and colorful ethnic cultures. The Manchu population is second only to Zhuang ethnic minorities, while the Manchu population in Liaoning Province accounts for more than half of Manchu's population. Therefore, promoting Manchu music culture and further developing Manchu national culture have positive and important significance for the protection and inheritance of the minority culture in Liaoning and even the Chinese minority culture. This article mainly briefly narrates the present situation of Manchu music culture in Liaoning Province and then explores the reasonable ways and means of protecting Manchu music culture in this area so as to promote the development of Manchu music culture.
\end{abstract}

Keywords-Manchu music culture; Liaoning area; inheritance and development

\section{INTRODUCTION}

Manchu full name Manchuria, formerly Manchukuo, banner people, Manmin, Renhai Revolution renamed Manchu Manchuria, is one of China's oldest ethnic minorities, is the largest branch of the Tungusic ethnic system, is also the only one twice in the Central Plains Region to establish the dynasty of the nation. As early as the pre-Qin period, the ancestor of Manchu was called Su Shen; the Tang Dynasty was called Sui Dynasty, and after Sui and Tang Dynasties, it was called the Jurchen. Manchu native language is Manchu, belongs to the Altaic language department - Tungusic language family. Ancient Manchu ancestors Su Shen people mainly live in north of Changbai Mountain, middle and upper reaches of Heilongjiang River, the Songhua River and other regions, while the Black River Sui Man is a Manchus ancestral ancestors, and later gradually developed into a Jurchen, the AD 12th century, The Jin Dynasty, which is also the first Manchu dynasty established by the regime. The establishment of the Jin dynasty played a positive role in consolidating the development of the national culture of the Jurchen nation, and the music culture of the Jain god also got enough development during this period. Year 1619 (Ming Wanli 47 years), Nuerhachi unified Jurchen ministries, the establishment of military and government banner of the Eight Banners system, known as the "gold." In 1635, Emperor Taiji succeeded to the throne and changed his country name to "Qing", abolishing the old name of Jurchen and changing the name to Manchu. After the Qing troops entered the country in 1644, they unified Central Plains.
With the establishment of the Qing dynasty, the Manchus and other ethnic people in the Central Plains began a long history of living together. The Manchu culture began to absorb the essence of the Han culture and gradually developed its own culture. However, The content of its own national music culture is mainly formed in the Kanto region, especially the birthplace of the Manchu - Liaoning region, so the music culture in this region is the fundamental place of Manchu music culture.

Manchu is a nation with a long history of more than 7000 years. The Manchu people are diligent, brave, kind, generous and can sing and dance. The ancestors of the whole nation live in the vast white mountains and black waters of the vast Kanto land. The Manchu culture also flourishes and is active in this land On the rich and colorful, goes back to ancient times, dating back thousands of years of history, the formation of a unique national musical culture. As a birthplace of Manchu, Liaoning has a large population of Manchu and about 5.5 million Manchu people are active in this prosperous region, accounting for $51 \%$ of Manchu's total population. In recent years, more and more music scholars have made outstanding contributions to the inheritance and protection of Manchu music in order to promote the inheritance of Manchu music culture. Studying Manchu music related culture in Liaoning Province plays an active role in studying Manchu culture and at the same time building relevant ideas about the future development of Manchu music in order to protect and promote Manchu music culture and make it b loom with its unique luster.

The excavation, research, inheritance and protection of any one art are not "closed doors" and "one action". It takes generations of unremitting efforts to get the result. Revitalizing Manchu music art and promoting Manchu music culture are not only the responsibility of researchers of Manchu music culture, but also the responsibility of many music art researchers. The study of Manchu music culture in Liaoning wants to get enough development mainly from the aspects of exploring the basic theory content and inheriting the way of development.

\section{THE BASIC THEORETICAL CONTENT TO EXPLORE}

To explore the succession and future development of any national art, we must first understand the historical evolution and specific forms of this art category, including its artistic forms, artistic contents and so on. Apart from understanding 
the situation and content of conventional music and culture, it is also a part of musicians should pay more attention to further understanding the deep cultural connotation behind Manchu music. To understand Manchu music culture, we should learn to understand the traditional Manchu language. Language and musical art are inextricably linked. Only by mastering the artistic features of Manchu language can we accurately grasp the essence of Manchu music and culture. The basic research of Liaoning Manchu music should be divided into different categories to be detailed analys is from all aspects, and ultimately to be written in detail. At the same time, we should not only confine ourselves to studying in the "studios" and "libraries", but also go to the folk and go to the wild countryside to visit the most authentic, most intuitive and most practical form of Manchu music. Only by better grasping the basic content of Manchu music culture and then grasping the connotation of Manchu music culture and the philosophical thoughts it reflects, can "take its essence and go to its dross" to carry out high-quality and profound second-level processing and creation of Manchu music, So that it can not only accord with the development of the times but also not deviate from the deep ideological connotation of its national music culture. Only in this way can we promote the music culture of Manchu in Liaoning province better and make the music of Liaoning Manchu have a unique regional culture Features.

\section{THE METHOD OF INHERITANCE AND DEVELOPMENT METHODS}

The development and inheritance of any one art can not be separated from the background of the times and the social environment in which they are located. The most effective way to achieve long-term development and good protection of a national musical art is to incorporate it into daily education. Not only refers to higher education here, but also includes basic education. Higher education can rely on specialization education and set up relevant national music culture disciplines. For example, it offers courses on the study of the music of the Manchu culture in professional art colleges and universities in Liaoning Province, such as shaman music studies, Manchu music Art and cultural history, Manchu choreography and other related professional courses. The opening of these courses, can train a large number of professional Manchu music and culture "communicators", is Manchu music into formal orbit. At the same time, we can also open up relevant courses on the history of the development of Manchu as well as folk studies and Manchu language among liberal arts professionals in higher education to publicize Manchu culture. This is also an introduction to protect the Manchu music culture. At the same time, local culture and education can be opened at the stage of local compulsory education. For example, basic Manchu classes and basic Manchu music and dance classes are set up in primary and secondary schools of six Manchu Autonomous County and two Manchu municipalities, so that Manchu children can learn from Manchu Music and cultural knowledge, develop their true national pride and national pride. Policy-level support is also very important. The government-related cultural management structure can regularly organize related mass activities of Manchu music art in Manchu Autonomous County and Manchu Autonomous City, such as Manchu dance performances and Manchu music and culture promotion and exhibition Multilevel, multi-faceted national and cultural exchanges. At the same time, the current media development has entered a new era. More and more people hope to participate in all-media activities and learn more knowledge at high speed and in depth through television, internet platform and mobile phone platform. At this time, the positive role of the media should be brought into full play. Various media should be used reasonably to enable the Manchu music culture to truly enter people's daily life so as to enhance the popularity of the Manchu music culture in the region and even the province. Without violating its basic art development Under the premise of the basic laws, the reasonable development and utilization of its artistic value, the use of more standardized market-oriented means of operation, combined with the local tourism resources, to achieve and Manchu music and cultural values corresponding to reflect the market value

\section{CONCLUSION}

It is the mission of every musician to carry forward the national music culture and inherit the essence of the national music culture. Carrying forward and developing the Manchu music culture in Liaoning Province, uniting the essence of Manchu music and culture, and returning to the essence of Manchu music culture are the mission entrusted by every age to the responsible literary and art workers of our time, as well as the needs of the times and the needs of history. Through the unremitting efforts of generations of literary and art workers, one day not only the Manchu music culture in Liaoning Province but also the Manchu music culture throughout the country will be promoted and developed.

\section{REFERENCE}

[1] Guiteng Liu: "Pivot: 20 Years of Manchu Music Research", "Yuefu New Voice (Journal of Shenyang Conservatory of Music)" No.1 2005.

[2] Yuxia Gao,Miao Jia, Zhe Deng: "Manchu music and its research status", "Manchu Studies" 2013 the second period.

[3] Yuxia Gao, Miao Jia, Zhe Deng: "Manchu music and its research status", "Manchu Studies" 2013 the second period. 